\title{
Internationalization and Digitalization: Applying digital technologies to the internationalization process of small and medium-sized enterprises
}

\author{
Annaële Hervé, Christophe Schmitt and Rico Baldegger
}

\author{
" The biggest part of our digital transformation is changing the way we think." \\ Simeon Preston \\ Managing Director \& COO \\ FWD Insurance
}

\begin{abstract}
Digitalization is playing an increasingly important role in the growth of firms and is leading to structural and strategic transformations. The use of digital technologies presents new opportunities for SMEs to expand and succeed in foreign markets. The purpose of this paper is to investigate how the impact of digital technologies on the internationalization process of SMEs has been acknowledged in the literature. It offers an in-depth analysis of five of the most highly relevant recent scientific research papers. The findings are synthetized through key points that highlight how SMEs acting in foreign markets could benefit from digital technologies. This paper complements previous research on the international trade transition initiated by digital technologies and provides a new perspective on contemporary research regarding the internationalization of firms. It concludes by identifying implications for research by scholars seeking to further study the digital aspects of traditional theoretical models of internationalization.
\end{abstract}

\section{Introduction}

Businesses and societies are undergoing a process with multiple transformations. Both are operating within broader complex economic systems. Businesses themselves therefore must understand, in concrete terms, the many elements of dynamic interaction involved (Morua et al., 2015).

With the advent of digital technologies, a new social paradigm is emerging, and disruptive changes are an important part of future progress. Characterized by the convergence of many emerging technologies, whose core is data (big data, artificial intelligence, internet of things, etc.), digitalization leads firms to radical transformations in their systems and processes, as well as in their management methods and workforce. For instance, by reducing operating costs and improving interactions among ecosystem stakeholders - including customers, partners, suppliers and distributors nascent digital technologies are playing an increasingly important role in company growth (Nambisan, 2017; Reuber \& Fischer, 2011, 2014).
Digitalization has started to be addressed at a scientific level in the fields of entrepreneurship and management research, among others (Kraus et al., 2019). However, although international research has been fundamentally influenced by the pervasive effects of technological advances for many years, relatively few studies have investigated emergent digital technologies to theoretically understand and empirically test their attributes in international business management (Hannibal \& Knight, 2018; Brouthers et al., 2018, 2016; Neubert, 2018; Ojala et al., 2018; Stallkamp \& Schotter, 2018; Watson et al., 2018; Wittkop et al., 2018; Coviello et al., 2017; Strange \& Zucchella, 2017; Autio \& Zander, 2016; Tanev et al., 2015).

Our research builds upon the recent Hervé et al. (2020) paper, aiming to study the effects of digital technologies on the internationalization processes of small and medium-sized enterprises (SMEs). To this end, the research performs an in-depth analysis of five relevant scientific papers. By using insights and arguments from 


\section{Internationalization and Digitalization: Applying digital technologies to the internationalization process of small and medium-sized enterprises Annaële Hervé, Christophe Schmitt and Rico Baldegger}

the literature of international business (IB) and international entrepreneurship (IE), we identified four main fields of activities that are at the center of interest for entrepreneurs when acting in international businesses: cost, accessibility, resources and competences; market knowledge; distance and location; relational competences and partner networks. The purpose of our study is to provide a synthesis of the key insights articulated in the five papers and highlight the main impact of digital technologies on these four fields of activities. It aims to contribute to IB and IE research by offering a better understanding of how the use of digital technologies can lead to new entrepreneurial opportunities in foreign markets. This objective is grounded in the current need to contribute to the development of new theoretical foundations for empirical research on internationalization on the interface of IB and entrepreneurship (Keupp \& Gassmann, 2009).

By integrating new digital technologies into the value chain and managing a massive amount of data, firms are likely to seize new opportunities with innovative ways to reach potential customers and be instantaneously active on a global scale. In general, digitalization impacts internationalization processes of firms in terms of accessibility of resources, skills, and competence acquisition, as well as in terms of the potential for learning and knowledge-development in foreign markets (Coviello et al., 2017). Other parameters, like location and entry mode choices or time and expansion rate, are also influenced by digital technology usage.

However, in the literature, internationalization theories and models have not been adequately adapted to the possibilities and challenges provided by digital environments. This has been observed mainly through Johanson and Vahlne's (1977) stage model theory, which emphasizes a progressive engagement at the international level, while borders are now becoming more "dematerialized" (Stallkamp \& Schotter, 2018). By questioning this stream of thought, scientific debates about the potential impact of the digital context emerge and constitute the starting point of this research (Kriz \& Welch, 2018; Coviello et al., 2017). Based on theoretical insights from IB, IE and literature from digital entrepreneurship and information systems, the paper makes a contribution by providing a synthesis that outlines how digital technologies impact the internationalization process of SMEs. To conclude, we discuss the results and highlight suggestions for future research. The paper also responds to recent calls for more research on the phenomenological field of IB in digital contexts (Coviello et al., 2017).

\section{Literature Review}

\section{Internationalization of firms}

The internationalization of firms is a subject of interest for numerous scientific communities and has been addressed for several years. Over time, IB theories have suggested different internationalization approaches, that have been aimed mainly at large companies. The stage model approach considers internationalization as a linear and sequential process (Johanson \& Vahlne, 1977). According to this model, a firm's knowledge is acquired gradually over time through experience, which is the most crucial resource needed in foreign markets. The authors of the related Uppsala model consider market knowledge (general and experiential) combined with the commitment of resources, as factors influencing engagement decisions and ongoing business activities in foreign markets (Johanson \& Vahlne, 1977).

Although various IB theories have coexisted in the literature for several decades, the stage model has been often criticized and the scientific community has gradually relativized its universality (Knight \& Liesch, 2016; Welch et al., 2016; Welch \& Paavilainen Mäntymäki, 2014; Forsgren \& Hagström, 2007; Andersen, 1993; Sullivan \& Bauerschmidt, 1990). In response to taking a sequential approach, numerous authors have studied alternative internationalization paths (McAuley, 2010; Ruzzier et al., 2006; Nummela et al., 2006; Lu \& Beamish, 2001; Gankema et al., 2000; Coviello \& McAuley, 1999; Oviatt \& McDougall, 1995). The increasing emergence and growth of entrepreneurial firms aiming at rapid internationalization enabled the development of new perspectives on internationalization models that were more relevant for SMEs.

The emphasis on SMEs firms in scientific research clearly demonstrates their decisive role in global industries. This has given rise to a new current of research developed at the intersection of IB and entrepreneurship theories, now called IE. This research field specifically studies small and young firms that venture abroad from their inception or soon after their launch (Reuber et al., 2018; Autio, 2017; Knight \& Liesch, 2016; Jones et al., 2011; Baldegger \& Schueffel, 2009; Keupp \& Gassmann, 2009; Oviatt \& McDougall, 2005; 


\section{Internationalization and Digitalization: Applying digital technologies to the internationalization process of small and medium-sized enterprises Annaële Hervé, Christophe Schmitt and Rico Baldegger}

Rialp et al., 2005; Zahra \& George, 2002; Oviatt \& McDougall, 1994). Even if multinationals and small companies have a very similar process for managing their international activities (Oviatt \& McDougall, 1995), the impact of globalization on SMEs is particularly strong and even more significant than on large companies (Ruzzier et al., 2006). Furthermore, being more comfortable with technology and more reactive to innovations, small firms can be actively engaged in business outside of domestic markets, and thereby benefit from global trade despite having limited initial resources (Knight \& Liesch, 2016).

As these firms discover ways to quickly achieve their international objectives, the IE approach is better adapted than the traditional IB theories. However, although this emerging discipline has grown exponentially, the theoretical foundations of IE remain somewhat fragmented, and too generalized (Jones et al., 2011; Keupp \& Gassmann, 2009). Especially due to the lack of a common conceptual framework, IE scientific research has been dominated by concepts that emerge from mainstream IB theories (Keupp \& Gassmann, 2009).

\section{Digitalization in firms}

To explain the emergence of digital technologies, our research applied the insights of Autio (2017), along with Bell and Loane (2010). The first wave started in the early 2000s with the emergence of Web 2.0 technologies. The introduction of mobile operating systems (iPhone and Android), storage solutions on computer servers (cloud computing), learning algorithms, and big data technologies marked the next significant developments. Data feeds all of these technologies. Its collection and analysis have thus become more accessible for the development of user-centric and knowledge-driven products and services. Digital technologies, such as artificial intelligence, can now be applied to optimize production and distribution, to improve managerial decisions for market entry, to target new customers more effectively, to select relevant partners, to supplement advertising strategies, to take better pricing decisions and to make demand predictions (Kraus et al., 2019; Aagaard et al., 2019; Watson et al., 2018). 3-D printers also represent a crucial advance in manufacturing techniques and allow companies to revolutionize their production and better customize each product to meet the end users' needs. Another major technological advance is the Internet of Things (IoT). This consists of integrating sensors able to collect and process data into smart products and devices, which can thus communicate and interact with each other (Rüßmann et al., 2015). Finally, firms perceive new opportunities with blockchain technology, which has been defined as, "an open, distributed ledger that records transactions between two parties efficiently and in a verifiable and permanent way" (Iansiti \& Lakhani, 2017). Distributed ledger (aka "blockchain") technologies provide firms with storage and transmission of information that is transparent, secure and which operates without third parties based on code.

Thanks to these recent technological advances, powerful information processing and storage resources are now widely available. The widespread adoption of these constituent technologies creates an enabling business environment. On one hand, it enriches interactions between individuals and, on the other, opens opportunities to improve value creation. To recognize opportunities and take advantage of these available tools, companies are faced with a transformation across their entire organization and activities (Kraus et al., 2019; Matt et al., 2015; Porter \& Heppelmann, 2015; Bharadwaj et al., 2013). Moreover, because digital technologies support companies at different levels, whether for creating, producing, selling and marketing, delivering, or supporting, they also involve disruptive changes in the value chain (Porter \& Heppelmann, 2015).

Ross and colleagues (2017) distinguished two steps in the transformation; become digitized and become digital. The first step takes place at the operational level and involves standardizing business processes and optimizing operations by implementing technologies and software. The second step involves purely digital technologies to articulate, target, and personalize alternative offers in order to define a new value proposition. It is, therefore, by taking the opportunity to redefine its business model and activities that a company becomes digital (Aagaard et al., 2019; Kraus et al., 2019; Ross et al., 2017).

\section{Digital internationalization}

Since the late 1990s, online sales turned to a new internationalization model. By dematerializing borders and reducing costs, e-commerce fundamentally changed the way business was conducted (Tiessen et al., 2001). Exporting to foreign markets through online sales became a significant competitive strategy. is particularly true for SMEs (Gabrielsson \& Gabrielsson, 2011). 


\section{Internationalization and Digitalization: Applying digital technologies to the internationalization process of small and medium-sized enterprises Annaële Hervé, Christophe Schmitt and Rico Baldegger}

Table 1. International Trade under Globalization

\begin{tabular}{|l|l|}
\hline $\mathbf{2 0}^{\text {th }}$ century globalization & $\mathbf{2 1}^{\text {st }}$ century globalization \\
\hline $\begin{array}{l}\text { Physical goods, capital, and } \\
\text { labor-intensive flows }\end{array}$ & $\begin{array}{l}\text { Data, information and } \\
\text { knowledge flows }\end{array}$ \\
\hline $\begin{array}{l}\text { Exchanges of mainly monetized } \\
\text { transactions }\end{array}$ & $\begin{array}{l}\text { Greater exchanges of free } \\
\text { content and services }\end{array}$ \\
\hline $\begin{array}{l}\text { Mostly between advanced } \\
\text { economies and multinational } \\
\text { companies }\end{array}$ & $\begin{array}{l}\text { More participation of emerging } \\
\text { economies, SMEs, and } \\
\text { individuals }\end{array}$ \\
\hline $\begin{array}{l}\text { Need for transportation } \\
\text { infrastructure }\end{array}$ & Need for digital infrastructure \\
\hline $\begin{array}{l}\text { Slow diffusion of information } \\
\text { across borders }\end{array}$ & $\begin{array}{l}\text { Instant global diffusion and } \\
\text { access of information }\end{array}$ \\
\hline $\begin{array}{l}\text { Innovation capacity and flows } \\
\text { from advanced to emerging } \\
\text { economies }\end{array}$ & $\begin{array}{l}\text { Innovation capacity and flows } \\
\text { in both directions }\end{array}$ \\
\hline
\end{tabular}

Source: modified from Manyika et al., 2016

Often faced with a lack of resources, the internationalization path has increased SMEs' agility in targeting markets and expanding their network (Watson et al., 2018; Mathews et al., 2016; Bell \& Loane, 2010; Foscht et al., 2006). A study by Coviello and colleagues (2017) recognised that nascent digital technologies have democratised global consumption, paved the way to a wide database for knowledge acquisition in foreign markets, improved communication and information exchange, and facilitated cross-border transactions by increasing intangible flows and reducing location dependencies. These technologies will lead firms to base their production decisions more on proximity to customers than on production costs (Hannibal \& Knight, 2018; Strange \& Zucchella, 2017)

\section{Methodology}

\section{Data collection}

This review comprehensively presents the relevant literature and synthesizes the key insights on how digital technologies impact the internationalization process of established SMEs. Little previous research has focused on the integration of purely digital technologies into the internationalization process of established small firms. Therefore, due to an insufficient and highly fragmented research basis, a systematic approach could not be pursued. The limited number of articles corresponding to our criteria led the data collection towards a rather systematically performed traditional review.

The literature search was bound by specific factors. First, an articles search was performed with SAGE Journals, Google Scholar and Ulysses search engines, and came mainly from scholarly publishers, like Emerald, Springer, and Elsevier. Given the novelty of the subject, it was not possible to limit our research to peerreviewed articles. We have thus expanded our investigations to include conference papers. We started the search with two main terms, "internationalization" and "digitalization", which, however, did not yield sufficient results to allow further investigation. Therefore, the study broadly expanded the targeted research on themes and keywords: "internationalization theory", "international entrepreneurship", "digital internationalization", "digital technologies", "digital entrepreneurship", and "digital transformation". The search was limited to English papers in the period 20162018. Finally, we considered only articles that used the term "digitalization" in the sense of applying purely digital technologies.

\section{Data analysis}

Once the relevant articles were identified, we conducted an in-depth analysis and comparison of the articles. After completing the analysis, five suitable papers that offered more systematic reviews and incorporated most of the points found in other articles were selected. The 


\section{Internationalization and Digitalization: Applying digital technologies to the internationalization process of small and medium-sized enterprises Annaële Hervé, Christophe Schmitt and Rico Baldegger}

novelty of the field could explain the lack of systematic studies. Thus, our choice of these five articles allowed us to adopt a more systematic approach to the synthesis of the key insights. In addition, we observed that the five studies complement each other in terms of specific insights.

Each of the studies was analyzed based on the title, publication period, theoretical framework used, and key findings (Table 2). All studies were first reviewed at an aggregate level to determine general directions. Although the perspective of analysis differs greatly from one study to another, the synthesis we present here is designed through four selected fields of activities related to the main internationalizing criteria. These are: costs, accessibility, resources and competences; market knowledge; distance and localization; and relational competences and partner networks.

\section{Results}

Costs, accessibility, resources and competences

Coviello et al. (2017) and Brouthers et al. (2018, 2016) agree that digitalization has a positive impact and helps companies in managing the risks associated with potential additional costs from their operations abroad (liabilities of foreignness). In their arguments, these authors suggested that technological advances also dematerialized distribution and production channels. These circumstances allow companies to specifically decrease transaction costs in foreign markets. For example, the use of IoT will result in changes in the management of geographically dispersed value chains and thus allow firms to reduce costs related to their international production (Strange \& Zucchella, 2017). Furthermore, by exploiting digital tools, Autio and Zander (2016) argue that internationally active small firms can significantly reduce the amount of assets needed for operations, as well as cost of location specificity. Because commercial activities are managed remotely, SMEs operating digitally in international markets appear to be able to generate alternative revenues without making significant investments. Resource allocation in several markets, transaction timesavings, and more optimized decision-making processes are additional effects of digitalization.

At an international level, SMEs need to maintain a specific advantage that differentiates them from local competition. To achieve this, they can aim to maximize their entry-mode attractiveness by targeting a niche market and offering innovative high-quality products.
Another way is to collaborate with specific local distributors that are already integrated in a large network. By reducing operating costs and improving communication and interaction with all ecosystem stakeholders - including customers, partners, suppliers, and distributors - digital technologies present new opportunities in terms of skill sharing, open innovation, co-creation, and partnership between companies (Coviello et al., 2017).

\section{Market knowledge}

Stage model theories have emphasized that a firm's speed of internationalization depends heavily on its ability to acquire new knowledge about foreign markets. One of the most significant changes related to the acceleration of online exchanges is the ability to capture and disseminate a considerable amount of data (Neubert, 2018). As it is now possible to directly interact with customers, companies can better understand customer needs and personalize their services and offers. Furthermore, by enhancing machine-to-machine and machine-to-human interaction, IoT facilitates product customization. In addition, 3-D printers provide customers with greater influence over the design of their products and over the control of manufacturing origins (Strange \& Zucchella, 2017). Thanks to these technologies, firms will better meet end-user requirements. Digitalization in such ways provides new fundamental experiential knowledge to companies.

Autio and Zander (2016) suggested that by combining the theoretical principles of Lean Entrepreneurship with the use of digital technologies, like big data and analytics, companies can conduct market experiments faster and in more countries. This allows firms to test products and services directly on potential customers in advance, no matter their location in the world (Strange \& Zucchella, 2017). Thanks to these experiments and the market knowledge gained from them, companies have learned how to perform better and benefit from direct contact with consumers by better adapting and customizing their offers (Strange \& Zucchella, 2017). Thus, they can frequently introduce advanced versions of their products and services (Strange \& Zucchella, 2017; Brouthers et al., 2018, 2016). To improve their position abroad, companies use feedback and comments shared on user community platforms or social networks. These online apps are flourishing with the advent of digital technologies. For that reason, idea sharing is fundamental for market adaptation, as it allows companies to anticipate their marketing efforts, and deploy better-targeted marketing and prospecting 


\section{Internationalization and Digitalization: Applying digital technologies to the internationalization process of small and medium-sized enterprises Annaële Hervé, Christophe Schmitt and Rico Baldegger}

activities (Brouthers et al., 2018, 2016). By communicating with user communities, SMEs become more responsive to implementing the necessary measures and, consequently, optimizing speed and marketing gains.

Emerging digital technologies are based mainly on the accessibility of internal and external data (Neubert, 2018). The collection of this abundant data (for social or commercial networks, or intellectual market knowledge) is a valuable source of information for companies and reduces cross-border information asymmetry (Autio \& Zander, 2016). The data can be processed by predictive algorithms to assess a company's current conditions and future market attractiveness (Neubert, 2018). The decision-making process is also supported by more advanced data-mining techniques, such as machine learning. Based on artificial intelligence and statistical approaches, this technology helps firms to model and interpret collected data for strategic purposes. Market knowledge with deployment of user communities, data collection, and new sources of accessible information underline the market-based approach of most SMEs.

\section{Distance and location}

The digitalization effects on distance and location are manifested mainly by border dematerialization and the acceleration of internationalization operations. Not only can a company manage its international activities online, reduce psychological distances, and multiply targeted countries, but the activities will also be led by business networks and user communities. Nascent digital technologies are transforming the location and organization of manufacturing production worldwide and will encourage firms to favor decisions based on proximity with customers rather than production costs (Strange \& Zucchella, 2017). In their research, Autio and Zander (2016) affirm that digitalization offers greater transferability of firm-specific assets. It allows small, internationally active firms to benefit from reduced dependence on location-bound assets in home and host countries (Coviello et al., 2017).

SMEs are often strongly advised to use rapid access to international trade promoted by digitalization. These pioneer leading firms create new opportunities to manage their activities from a distance and thereby reach a larger number of markets with the same productive resources by, for example, externalizing location-specific assets. Another aspect linked to distance and location was raised by Brouthers and colleagues $(2018,2016)$. They argued that when entering a foreign market, SMEs are confronted with new internationalization obstacles called "liabilities of outsidership". This concept suggests that when a firm reaches a new market, it usually has few relations with other firms, and is consequently considered an outsider. Firms applying nascent digital technologies can counter this liability by generating value through the creation and coordination of a network of users via the construction and management of digital platforms.

However, although a platform is easily replicable from one country to another, transferring the user bases is more difficult. Therefore, small firms are forced to quickly reach a critical mass of users to establish themselves in foreign markets (Brouthers et al., 2018, 2016). A limited number of users does not encourage further interactions and makes market entry harder. And in most cases, because platform costs exceed expected profits, the expansion rate can be significantly slowed down. To counter this, companies need to succeed in attracting potential users to adopt and populate their platform, and rapidly develop a large community of users (Brouthers et al., 2018, 2016).

\section{Relational competences and partner networks}

Markets are mainly relationship networks that firms maintain with their distributors, suppliers and customers. Over time, internationalization theories have emphasized the importance of building and integrating networks on a global scale. However, the digital context challenges the very foundations of network theory, such that it is now necessary to fundamentally rethink our actual understanding of relationships across international trade (Autio and Zander, 2016).

First, there are a growing number of market participants acting on both sides, as sellers and as buyers (Coviello et al. 2017). This allows SMEs to integrate customers into their ecosystem and develop direct contact with them. More precisely, Strange and Zucchella (2017) argued that firms can now involve customers as providers of key information and feedback on products, and even as local manufacturers. These authors pointed out that the relationship between firms and customers changes dramatically and gets redefined in many ways. Second, markets are current, momentaneous and dedicated to specific transactions (Coviello et al., 2017). This makes it more difficult to conclude long-term relationships with actors integrated at the time into any network in question. Because digital technologies are increasing the number of instantaneous, brief and interrelated 


\section{Internationalization and Digitalization: Applying digital technologies to the internationalization process of small and medium-sized enterprises Annaële Hervé, Christophe Schmitt and Rico Baldegger}

interactions, the pace of these encounters is also accelerated. It thus allows firms to speed up their market adaptation to reach several new foreign markets at the same time (Coviello et al., 2017). Finally, the intensified used of the Internet has initiated and amplified the creation of one large virtual global "market" for trade involving economic and social transactions, as well as exchanges of tangible and intangible goods (Coviello et al., 2017). This development has led to a broadening market scope, and also afforded better access to local market actors and partners.

Thanks to the wide flow of data, SMEs are now often more oriented towards exchanges than production (Coviello et al., 2017). And these exchanges seem to provide new opportunities for international trade. Indeed, companies have increased access to local knowledge and simultaneously can enhance the reliability of their main relationships. By sharing data and skills with partners, SMEs have new possibilities for integrating targeted networks. To maintain these exchanges, decision-makers are recommended to set up processes and mechanisms to arrange relationships developed with a diversified and dispersed set of actors, both internally and externally (Coviello et al., 2017). Small firms likewise should aim to multiply user communities in several countries, while making sustained use of social networks and mass media deployed there (Brouthers et al., 2018, 2016). In their research, Brouthers and colleagues $(2018,2016)$ also suggested collaborating with opinion leaders and change agents in foreign markets. These well-known actors and public figures can serve as powerful levers in social media and user communities around the world. They can help a company become known quickly and build its online reputation, resulting in small firms internationalizing faster.

\section{Discussion}

This paper combines two research streams to understand their links and relationships. Through our observations, we first noticed a lack of congruence in internationalization research between existing models and the actual environments in which SMEs operate. Then, by taking into consideration scientific research focused on digitalization, we found that there are many untapped entrepreneurial opportunities for firms to undertake successful international trade. These findings corroborated the need to address the digital issue on traditional internationalization theories and allowed us to highlight the main effects of digital technologies on the activities of small firms abroad. Through the results shown in Table 3, we clarified how SMEs can use digital technologies to achieve successful international activities.

International trades are transforming and dematerializing the rate of digitalization. Our results highlighted the dynamic of a current, international environment constantly in movement. SMEs are immediately connected on a global scale without necessarily requiring specific resources or business networks. Here are some of their impacts:

- they are threatening large companies by sharing their skills via large groups of entrepreneurs;

- transaction costs are significantly reduced;

- communication, distribution, and production channels are dematerialized;

- markets are virtual, instantaneous, and more competitive;

- physical flows are giving way to data flows;

- geographical distances are virtually reduced and allow partner networks to largely dominate trade negotiations between nations;

- seller and buyer meet directly, regardless of distance or time zones;

- consumers are directly integrated into development and internationalization processes; and,

- the emergence of user communities and social media enables firms to test and adapt offers to local markets and, in some cases, to diversify activities.

Digitalization has removed many international barriers and allows larger SMEs to engage in international markets and act like micro-multinationals. Nevertheless, the impact of fundamental uncertainty (Kraus et al., 2019; Ojala et al., 2018) and the need to take into account non-linearity and interdependencies in the internationalization process, increase complexities for 


\section{Internationalization and Digitalization: Applying digital technologies to the internationalization process of small and medium-sized enterprises Annaële Hervé, Christophe Schmitt and Rico Baldegger}

entrepreneurs, and have a direct impact on the entrepreneurial competences needed in foreign markets. Thanks to our research, we noticed that entrepreneurs and managers are widely encouraged to effectively integrate their organizational capacities and skills, strategically position themselves as market participants, and actively drive their own ongoing digital transformation.

Nowadays, the use of technologies impacts firms by enabling a transformation of not only their operations, offerings and value propositions, but also by enhancing their interactions with customers. Furthermore, it supports the firms' numerous organizational and strategic aspects and allows them to overcome several internal barriers. For instance, at a strategic level, nascent digital technologies affect the configuration and coordination of the entire value chain. They can create essential networks and sources of data that aid and allow firms to directly find investors, recruit talent, and solicit opinion leaders or change agents. Our findings show that digitalizing business functions could involve redesigning a firm's business model in a way that enables new opportunities for internationalizing, creating value, and developing customer relationships. For instance, digitalization facilitates a "servitization" transition in some companies, which means adding different services to complement an earlier product offer, and, thus, adds support for the customer in a broader way (Aagaard et al., 2019).

There are essential factors involved when defining the international scalability of an SME's business model. A B2C-oriented business model designed to reach critical mass that combines with user engagement and a collaborative approach is one of these essential factors. Digitalization will also change the production, transportation, and logistics patterns. In their research, Hannibal and Knight (2018) mentioned the "deglobalized" production and other strategic opportunities with regard to diversification. For example, the use of 3D-printers will allow firms to base their production site closer to consumers and, in this way, favor customization and reduction of transportation and logistics costs. Based on these results, our research calls into question the "international" dimension of international trade. Instantaneous access to foreign markets is a reality and, as shown in our results, a greater role to be played by nascent digital technologies is just beginning to happen.

\section{Conclusion and Agenda for Future Research}

In the light of increasing digitalization, our paper contributes to the literature by providing a new perspective on contemporary research involving internationalizing companies. It presented an in-depth analysis of five scientific research papers and aimed at understanding international trades in transition as initiated by global digital technologies. From a managerial point of view, our study addressed digitalization issues involved at the firm's structural and strategic level. Linked with standard internationalization criteria, key points identified in our research (Table 3) show how managers acting in foreign markets could benefit from digital technologies.

We are convinced that the convergence of globalization and digitalization clearly demonstrates the need for business leaders and decision-makers to reassess their strategies. As we are still early in the digital era, significant opportunities remain to be seen. However, most managers currently have little theoretical knowledge of digitalization history or trends. Managers may benefit from the use of digital tools in several ways if they can rapidly master and integrate them into their internationalization process. The faster a company understands the benefits of using digital technologies, the faster it can improve its decision-making processes and accelerate its internationalization speed (Neubert, 2018).

In these circumstances, future research should focus on using quantitative and qualitative data to empirically study the effects of digitalization on internationalization processes. Such data would be valuable to help define how the use of digital technologies affects internationalization models and strategies. In the literature, the risks of digitalization in international trade are not empirically addressed. Although the research we conducted agreed that the use of digital tools has a positive effect on international expansion, the limits of digitalization could be an avenue for future research. Indeed, risks related to digital internationalization, like the increase of price pressures, intensification of aggressive global competitiveness, cybercrime, and the lack of global legal protections, are some examples of topics still largely unexplored. Concerning legal protection, new institutional arrangements and standards will emerge to regulate the growing interconnectivity and complexity generated by 


\section{Internationalization and Digitalization: Applying digital technologies to the internationalization process of small and medium-sized enterprises Annaële Hervé, Christophe Schmitt and Rico Baldegger}

digital environment, and companies will likewise face new entry barriers and regulatory compliances imposed by governments.

Another interesting research orientation related to digital internationalization is the context of emerging economies. Because the world is more interconnected than ever, scientific research related to internationalization theories should pay more attention to emerging countries, where a multitude of niche markets are rapidly flourishing thanks largely to digitalization, and its "leapfrog" potential. It is the first time in history that emerging markets have become counterparts in more than half of global trade flows, while South-South trade between nations is the fastestgrowing type of connection (Manyika et al., 2016). In view of the above, research into internationalization has, therefore, many unexplored avenues of study open and available regarding digital transformation. Researchers should focus on empirical data collection and adapt their approach to realities on the ground (Delios, 2017). Future research on digitalization needs to build new theoretical models better adjusted to the current international trade environment than the frameworks commonly found in the literature.

\section{References}

Aagaard, A., Aagaard, A., \& Harrison. 2019. Digital Business Models. Springer International Publishing.

Andersen, O. 1993. On the internationalization process of firms: A critical analysis. Journal of International Business Studies, 24(2): 209-231.

Autio, E. 2017. Digitalisation, Ecosystems, Entrepreneurship and Policy. Perspectives into Topical Issues Is Society and Ways to Support Political Decision Making. Government's Analysis, Research and Assessment Activities Policy Brief, 20.

Autio, E., Nambisan, S., Thomas, L. D., \& Wright, M. 2018. Digital affordances, spatial affordances, and the genesis of entrepreneurial ecosystems. Strategic Entrepreneurship Journal, 12(1): 72-95.

Autio, E., \& Zander, I. (2016). Lean internationalization. In Academy of Management Proceedings, Vol. 2016, No. 1: 17420.

Baldegger, R., \& Schueffel, P. 2009. Le comportement d'internationalisation des PME suisses: born global et internationalisation progressive. Revue internationale PME: Économie et gestion de la petite et moyenne entreprise, 22(1) : 9-45.

Bell, J., \& Loane, S. 2010. 'New-wave'global firms: Web 2.0 and SME internationalisation. Journal of Marketing Management, 26(3-4): 213-229.
Bharadwaj, A., El Sawy, O., Pavlou, P., \& Venkatraman, N. 2013. Digital business strategy: toward a next generation of insights. MIS Quarterly, Vol. 37, No. 2: 471-482

Brouthers, K.D., Geisser, K.D., \& Rothlauf, F. 2018. Explaining the internationalization of ibusiness firms. International Entrepreneurship: The Pursuit of Opportunities across National Borders: 217-264.

Brouthers, K.D., Geisser, K.D., \& Rothlauf, F. 2016. Explaining the internationalization of ibusiness firms. Journal of International Business Studies: 1-22.

Coviello, N.E., \& McAuley, A. 1999. Internationalisation and the smaller firm: A review of contemporary empirical research. MIR: Management International Review: 223-256.

Coviello, N., Kano, L., \& Liesch, P.W. 2017. Adapting the Uppsala model to a modern world: Macro-context and microfoundations. Journal of International Business Studies, 48(9): 1151-1164.

Delios, A. 2017. The death and rebirth (?) of international business research. Journal of Management Studies, 54(3): 391-397.

Forsgren, M., \& Hagström, P. 2007. Ignorant and impatient internationalization? The Uppsala model and internationalization patterns for Internet-related firms. Critical Perspectives on International Business, 3(4): 291-305.

Foscht, T., Swoboda, B., \& Morschett, D. 2006. Electronic commerce-based internationalisation of small, nicheoriented retailing companies: The case of Blue Tomato and the Snowboard industry. International Journal of Retail \& Distribution Management, 34(7): 556-572.

Gabrielsson, M., \& Gabrielsson, P. 2011. Internet-based sales channel strategies of born global firms. International Business Review, 20(1): 88-99.

Gankema, H.G. J., Snuif, H.R. and Zwart, P.S. 2000. The Internationalization Process of Small and Medium Sized Enterprises: An Evaluation of Stage Theory. Journal of Small Business Management, 38(4): 15-27.

Hannibal, M., \& Knight, G. 2018. Additive manufacturing and the global factory: Disruptive technologies and the location of international business. International Business Review, 27(6): 1116-1127.

Hervé, A., Schmitt, C., \& Baldegger, R. 2020. Digitalization, Entrepreneurial Orientation and Internationalization of Micro-, Small- and MediumSized Enterprises. Technology Innovation Management Review, 10(4): 5-17.

http://doi.org/10.22215/timreview/1343

Iansiti, M., \& Lakhani, K.R. 2017. The truth about blockchain. Harvard Business Review, 95(1): 118-127.

Johanson, J., \& Vahlne, J.E. 1977. The internationalization process of the firm - a model of knowledge development and increasing foreign market commitments. Journal of International Business Studies, 8(1): 23-32. 


\section{Internationalization and Digitalization: Applying digital technologies to the internationalization process of small and medium-sized enterprises Annaële Hervé, Christophe Schmitt and Rico Baldegger}

Jones, M.V., Coviello, N., \& Tang, Y.K. 2011. International entrepreneurship research (1989-2009): a domain ontology and thematic analysis. Journal of Business Venturing, 26(6): 632-659.

Keupp, M.M., \& Gassmann, O. 2009. The past and the future of international entrepreneurship: a review and suggestions for developing the field. Journal of Management, 35(3): 600-633.

Knight, G.A., \& Liesch, P.W. 2016. Internationalization: From incremental to born global. Journal of World Business, 51(1): 93-102.

Kraus, S., Palmer, C., Kailer, N., Kallinger, F.L., \& Spitzer, J. 2019. Digital entrepreneurship: a research agenda on new business models for the twenty-first century. International Journal of Entrepreneurial Behavior \& Research, 25(2): 353-375.

Kriz, A., \& Welch, C. 2018. Innovation and internationalisation processes of firms with new-tothe-world technologies. Journal of International Business Studies, 49(4): 496-522.

Lu, J.W., \& Beamish, P.W. 2001. The internationalization and performance of SMEs. Strategic Management Journal, 22(6 7): 565-586.

Manyika, J., Lund, S., Bughin, J., Woetzel, J. R., Stamenov, K., \& Dhingra, D. 2016. Digital globalization: The new era of global flows (Vol. 4). San Francisco: McKinsey Global Institute.

Mathews, S., Bianchi, C., Perks, K. J., Healy, M., \& Wickramasekera, R. 2016. Internet marketing capabilities and international market growth. International Business Review, 25(4): 820-830.

Matt, C., Hess, T., \& Benlian, A. 2015. Digital transformation strategies. Business \& Information Systems Engineering, 57(5): 339-343.

McAuley, A. 2010. Looking Back, Going Forward: Reflecting on Research into the SME Internationalisation Process. Journal of Research in Marketing and Entrepreneurship, 12 (1): 21-41.

Morua, J., Marin A., Schmitt C. 2015. Through a dynamical representation of the firm to manage the complexity of innovation strategy. The 19th world multi-conference on systemics, cybernetics and informatics: WMSCI 2015, July 12-15, Orlando, Florida, USA.

Nambisan, S. 2017. Digital entrepreneurship: Toward a digital technology perspective of entrepreneurship. Entrepreneurship Theory and Practice, 41(6): 10291055.

Neubert, M. 2018. The Impact of Digitalization on the Speed of Internationalization of Lean Global Startups. Technology Innovation Management Review, 8(5).

Nummela, N., Loane, S. \& Bell, J. 2006. Change in SME Internationalisation: an Irish Perspective. Journal of Small Business and Enterprise Development, 13 (4): 562-83.
Ojala, A., Evers, N., \& Rialp, A. 2018. Extending the international new venture phenomenon to digital platform providers: A longitudinal case study. Journal of World Business, 53(5): 725-739.

Oviatt, B.M., \& McDougall, P.P. 1994. Toward a theory of international new ventures. Journal of International Business Studies, 25(1): 45-64.

Oviatt, B.M., \& McDougall, P.P. 1995. Global start-ups: Entrepreneurs on a worldwide stage. Academy of Management Perspectives, 9(2): 30-43.

Oviatt, B.M., \& McDougall, P.P. 2005. Defining international entrepreneurship and modeling the speed of internationalization. Entrepreneurship Theory and Practice, 29(5): 537-553.

Porter, M.E., \& Heppelmann, J.E. 2015. How smart, connected products are transforming companies. Harvard Business Review, 93(10): 96-114.

Reuber, A.R., \& Fischer, E. 2011. International entrepreneurship in internet-enabled markets. Journal of Business Venturing, 26(6): 660-679.

Reuber, A.R., Fischer, E., \& Morgan-Thomas, A. 2014. Understanding eINVs through the lens of prior research in entrepreneurship, international business and international entrepreneurship. The Routledge Companion to International Entrepreneurship: 165185.

Reuber, A.R., Knight, G.A., Liesch, P.W., \& Zhou, L. 2018. International entrepreneurship: The pursuit of entrepreneurial opportunities across national borders. Journal of International Business Studies.

Rialp, A., Rialp, J., \& Knight, G.A. 2005. The phenomenon of early internationalizing firms: what do we know after a decade (1993-2003) of scientific inquiry? International Business Review, 14(2): 147-166.

Ross, J., Beath, C., Sebastian, I. 2017. Digitized Digital. MIT Center for Information Systems Research. Research Briefing. Volume XVII, Number 10.

Rüßmann, M., Lorenz, M., Gerbert, P., Waldner, M., Justus, J., Engel, P., \& Harnisch, M. 2015. Industry 4.0: The future of productivity and growth in manufacturing industries. Boston Consulting Group, 9(1): 54-89.

Ruzzier, M., Hisrich, R.D., \& Antoncic, B. 2006. SME internationalization research: past, present, and future. Journal of Small Business and Enterprise Development, 13(4): 476-497.

Sinkovics, N., Sinkovics, R.R., \& “Bryan” Jean, R.J. 2013. The internet as an alternative path to internationalization? International Marketing Review, 30(2): 130-155.

Stallkamp, M., \& Schotter, A.P. 2018. Platforms without borders? The international strategies of digital platform firms. Global Strategy Journal.

Strange, R., \& Zucchella, A. 2017. Industry 4.0, global value chains and international business. Multinational Business Review, 25(3): 174-184. 


\section{Internationalization and Digitalization: Applying digital technologies to the internationalization process of small and medium-sized enterprises Annaële Hervé, Christophe Schmitt and Rico Baldegger}

Sullivan, D., \& Bauerschmidt, A. 1990. Incremental internationalization: a test of Johanson and Vahlne's thesis. MIR: Management International Review: 19-30.

Tanev, S., Rasmussen, E.S., Zijdemans, E., Lemminger, R., \& Svendsen, L.L. 2015. Lean and global technology start-ups: linking the two research streams. International Journal of Innovation Management, 19(03): 1540008.

Tiessen, J.H., Wright, R.W., \& Turner, I. 2001. A model of e-commerce use by internationalizing SMEs. Journal of International Management, 7(3): 211-233.

Vahlne, J.E., \& Johanson, J. 2017. From internationalization to evolution: The Uppsala model at 40 years. Journal of International Business Studies, 48(9): 1087-1102.

Watson, G., Weaven, S., Perkins, H., Sardana, D., \& Palmatier, R. 2018. International Market Entry Strategies: Relational, Digital, and Hybrid Approaches. Journal of International Marketing, 26(1): 30-60.

Welch, C., \& E. Paavilainen Mäntymäki. 2014. Putting Process (back) in: Research on the Internationalisation Process of the Firm. International Journal of Management Reviews, 16 (1): 2-23.

Welch, C., Nummela, N., \& Liesch, P. 2016. The internationalization process model revisited: An agenda for future research. Management International Review. Volume 56, Issue 6: 783-804.

Wittkop, A., Zulauf, K., \& Wagner, R. 2018. How digitalization changes the internationalization of entrepreneurial firms: theoretical considerations and empirical evidence. Management Dynamics in the Knowledge Economy, 6(2): 193-207.

Zahra, S.A., Matherne, B.P., \& Carleton, J.M. 2003. Technological resource leveraging and the internationalisation of new ventures. Journal of International Entrepreneurship, 1(2): 163-186.

\section{About the Authors}

Annaële Hervé is a $\mathrm{PhD}$ candidate at the Université de Lorraine. Her thesis addresses the research streams of digitalization and internationalization of MSMEs. She holds a Bachelor's degree in Management as well as a Master degree in Entrepreneurship. She is also working part time at the research department of the School of Management Fribourg in Switzerland. Her main research interests are digital transformation of firms, digital business model as well as international entrepreneurship.

Prof. Christophe Schmitt is a Professor in Entrepreneurship at the Université de Lorraine (IAE de Metz and CEREFIGE), he holds the research Chair "Entreprendre", and he is responsible for PeeL (the Lorraine Student Entrepreneurship Pole). He is also an Associate Professor at the Louvain School of Management in Belgium and at the School of Management Fribourg in Switzerland. His articles and books mostly concern the notion of value design and knowledge building for action as well as the development of entrepreneurial practices.

Prof. Rico Baldegger is Director and Professor of Strategy, Innovation and Entrepreneurship at the School of Management Fribourg (HEG-FR), Switzerland. He has studied at the Universities of St. Gallen and Fribourg, Switzerland. His research activities concentrate on innovative start-ups, the entrepreneurial behavior of individuals and organizations, as well as the phenomenon of rapidgrowth companies. He has published several books and articles and, since the beginning of the 1990s, he has been the manager of a business for company development. Moreover, he is a business angel and serial entrepreneur, as is demonstrated by the many companies he has created.
Citation: Hervé, A., Schmitt, C., Baldegger, R. 2020. Internationalization and
Digitalization: Applying digital technologies to the internationalization
process of small and medium-sized enterprises. Technology Innovation
Management Review, 10(7): 28-40.
http://doi.org/10.22215/timreview/1373

Keywords: Internationalization, international business, digital entrepreneurship, digitalization, digital technologies, SMEs. 


\section{Internationalization and Digitalization: Applying digital technologies to the internationalization process of small and medium-sized enterprises Annaële Hervé, Christophe Schmitt and Rico Baldegger}

Appendix - Table 2. Overview of selected papers used in the synthesis

\begin{tabular}{|c|c|c|c|c|c|}
\hline $\begin{array}{c}\text { Authors } \\
\text { (year) }\end{array}$ & Title & $\begin{array}{c}\text { Scientific } \\
\text { review }\end{array}$ & Research objective & $\begin{array}{l}\text { Theoretical } \\
\text { framework }\end{array}$ & Key results \\
\hline $\begin{array}{l}\text { Autio and } \\
\text { Zander } \\
(2016)\end{array}$ & $\begin{array}{l}\text { Lean } \\
\text { international- } \\
\text { ization }\end{array}$ & $\begin{array}{l}\text { Academy of } \\
\text { Management } \\
\text { Proceedings }\end{array}$ & $\begin{array}{l}\text { This research explores } \\
\text { how digitalization } \\
\text { impacts expansion } \\
\text { processes of INVs. By } \\
\text { focusing on their } \\
\text { business operations, } \\
\text { authors explain how the } \\
\text { use of digital tools affects } \\
\text { international trade. }\end{array}$ & $\begin{array}{l}\text { Transaction cost } \\
\text { theory } \\
\text { Foreign entry } \\
\text { mode } \\
\text { International } \\
\text { Entrepreneurship }\end{array}$ & $\begin{array}{l}\text { Through several proposals, the } \\
\text { researchers present the main effects } \\
\text { of digitalization on the INV } \\
\text { internationalization process. Their } \\
\text { proposals suggest that digitalization } \\
\text { mainly reduces geographical } \\
\text { distances, the specificity of vertical } \\
\text { and horizontal assets, and cross- } \\
\text { border information asymmetries. By } \\
\text { linking lean entrepreneurship } \\
\text { practices to digitalization, the } \\
\text { authors formulate a new theoretical } \\
\text { lens: Lean Internationalization. }\end{array}$ \\
\hline $\begin{array}{l}\text { Coviello and } \\
\text { al. (2017) }\end{array}$ & $\begin{array}{l}\text { Adapting the } \\
\text { Uppsala model } \\
\text { to a modern } \\
\text { world: Macro- } \\
\text { context and } \\
\text { micro- } \\
\text { foundations }\end{array}$ & $\begin{array}{l}\text { Journal of } \\
\text { International } \\
\text { Business } \\
\text { Studies }\end{array}$ & $\begin{array}{l}\text { This study is a } \\
\text { counterpoint to the last } \\
\text { Uppsala Model version } \\
\text { (2017). It examines two } \\
\text { missing dimensions to } \\
\text { the model: the impact of } \\
\text { the digital context at a } \\
\text { macroeconomic level } \\
\text { and the role of decision- } \\
\text { makers at a } \\
\text { microeconomic level. }\end{array}$ & $\begin{array}{l}\text { International } \\
\text { Business } \\
\text { Entrepreneurship } \\
\text { International } \\
\text { Entrepreneurship }\end{array}$ & $\begin{array}{l}\text { Research results underpin the } \\
\text { importance of studying the digital } \\
\text { context at a macroeconomic level to } \\
\text { create and exploit new opportunities } \\
\text { in foreign markets. Based on the } \\
\text { Uppsala model, the authors develop } \\
\text { a three-level conceptual framework. } \\
\text { This model integrates the macro and } \\
\text { micro characteristics studied in their } \\
\text { counterpoint. }\end{array}$ \\
\hline $\begin{array}{l}\text { Strange and } \\
\text { Zucchella } \\
\text { (2017) }\end{array}$ & $\begin{array}{l}\text { Industry } 4.0, \\
\text { Global Value } \\
\text { Chains and } \\
\text { International } \\
\text { Business }\end{array}$ & $\begin{array}{l}\text { Multinational } \\
\text { Business } \\
\text { Review }\end{array}$ & $\begin{array}{l}\text { Based on the main digital } \\
\text { technologies (IoT, big } \\
\text { data and analytics, } \\
\text { robotic systems, and 3D- } \\
\text { printers), this research } \\
\text { aims to assess how their } \\
\text { adoption impacts the } \\
\text { location and } \\
\text { organization of activities } \\
\text { in global value chains. }\end{array}$ & $\begin{array}{l}\text { Industry } 4.0 \\
\text { International } \\
\text { Business }\end{array}$ & $\begin{array}{l}\text { The authors report the way in which } \\
\text { digital technologies are disrupting } \\
\text { how and where activities are located } \\
\text { and organized within global value } \\
\text { chains as well as who captures the } \\
\text { value added within those chains. } \\
\text { Through real facts, their research } \\
\text { explains the concrete effects of } \\
\text { digital technologies on the practice } \\
\text { and theory of international business. }\end{array}$ \\
\hline $\begin{array}{l}\text { Brouthers } \\
\text { etal. (2018, } \\
\text { 2016) }\end{array}$ & $\begin{array}{l}\text { Explaining the } \\
\text { international- } \\
\text { isation of } \\
\text { business firms }\end{array}$ & $\begin{array}{l}\text { Journal of } \\
\text { International } \\
\text { Business } \\
\text { Studies }\end{array}$ & $\begin{array}{l}\text { The authors extend } \\
\text { internationalization } \\
\text { theories to digital firms. } \\
\text { Based on a literature } \\
\text { review and case studies, } \\
\text { they examine and } \\
\text { compare the } \\
\text { internationalization } \\
\text { process of such firms. }\end{array}$ & $\begin{array}{l}\text { International } \\
\text { Business } \\
\text { Social network } \\
\text { theory } \\
\text { Diffusion of } \\
\text { innovation } \\
\text { theory }\end{array}$ & $\begin{array}{l}\text { Thanks to the use of platforms, the } \\
\text { authors suggest that digital firms are } \\
\text { less impacted by the liabilities of } \\
\text { foreignness. On the other hand, these } \\
\text { digital companies might suffer from } \\
\text { a lack of relationship with existing } \\
\text { networks and be faced with more } \\
\text { difficulties in developing potential } \\
\text { collaboration across foreign markets } \\
\text { (liabilities of outsidership). Based on } \\
\text { a multi-case study, their research } \\
\text { develops a new theory and testable } \\
\text { hypotheses. }\end{array}$ \\
\hline $\begin{array}{l}\text { Neubert } \\
(2018)\end{array}$ & $\begin{array}{l}\text { The impact of } \\
\text { digitalization } \\
\text { on the speed of } \\
\text { internationaliz } \\
\text { ation of lean } \\
\text { global startups }\end{array}$ & $\begin{array}{l}\text { Technology } \\
\text { Innovation } \\
\text { f Management } \\
\text { Review }\end{array}$ & $\begin{array}{l}\text { This research aims to } \\
\text { demonstrate how the use } \\
\text { of digital technologies in } \\
\text { the expansion process } \\
\text { accelerates the } \\
\text { internationalization rate } \\
\text { of Lean Global Start-ups. }\end{array}$ & $\begin{array}{l}\text { Lean Global } \\
\text { Startup } \\
\text { International } \\
\text { market } \\
\text { development } \\
\text { processes }\end{array}$ & $\begin{array}{l}\text { Results confirm a significant and } \\
\text { positive impact of digitalization on } \\
\text { the start-up internationalization } \\
\text { process. The authors suggest that the } \\
\text { integration of digital technologies } \\
\text { allows companies to deploy new } \\
\text { knowledge, to rapidly integrate } \\
\text { relational network, to improve the } \\
\text { efficiency of decision-making } \\
\text { processes and, finally, to accelerate } \\
\text { the speed of internationalization. }\end{array}$ \\
\hline
\end{tabular}




\section{Internationalization and Digitalization: Applying digital technologies to the internationalization process of small and medium-sized enterprises Annaële Hervé, Christophe Schmitt and Rico Baldegger}

Appendix - Table 3. Digital effects and opportunities for international trades

\begin{tabular}{|c|c|c|}
\hline & $\begin{array}{l}\text { Digitalization effects on } \\
\text { internationalization activities }\end{array}$ & $\begin{array}{l}\text { Opportunities for defining new value propositions } \\
\text { through digital use }\end{array}$ \\
\hline \multirow{7}{*}{$\begin{array}{l}\text { Costs, accessibility, } \\
\text { resources, and } \\
\text { competences }\end{array}$} & \multirow{7}{*}{$\begin{array}{l}\text { - dematerialization of distribution and } \\
\text { production channels } \\
\text { - reduction of assets and location specificity } \\
\text { - improvement of interaction and exchanges } \\
\text { - reduction of additional cost for foreign } \\
\text { operations } \\
\text { - resource allocation in several markets } \\
\text { - time-saving transactions } \\
\text { - optimization of decision-making processes } \\
\text { - asset specificity attenuated } \\
\text { - acquisition of specific resources and } \\
\text { competences } \\
\text { - reduction of customers' acquisition costs }\end{array}$} & $\begin{array}{l}\text { Alternative revenue through digital platforms and } \\
\text { infrastructures } \\
\text { Targeting niche markets and innovative high-quality } \\
\text { products }\end{array}$ \\
\hline & & Sharing of skills and capacities between companies \\
\hline & & $\begin{array}{l}\text { Open innovation and co-creation with partners and } \\
\text { customers }\end{array}$ \\
\hline & & Partnership with other companies \\
\hline & & $\begin{array}{l}\text { Integrating Io } T \text { into the value chain to reduce } \\
\text { production costs }\end{array}$ \\
\hline & & Local market development \\
\hline & & Investment in qualified human capital \\
\hline \multirow{7}{*}{$\begin{array}{l}\text { Market knowledge } \\
\text { (general and based } \\
\text { on experience) }\end{array}$} & \multirow{7}{*}{$\begin{array}{l}\text { - accessibility to large information databases } \\
\text { - exchange and processing of large amounts of } \\
\text { data } \\
\text { - deployment of numerous online user } \\
\text { community platforms or social networks } \\
\text { - faster and more efficient adaptation to markets } \\
\text { - better analyses of market attractiveness } \\
\text { - optimization of internationalization speed and } \\
\text { - marketing gains } \\
\text { - cross-border information asymmetry } \\
\text { - more efficient decision-making processes } \\
\text { - emergence of more advanced data-mining } \\
\text { techniques (machine learning) }\end{array}$} & $\begin{array}{l}\text { Better customize and personalize offers, services and } \\
\text { the customer experience }\end{array}$ \\
\hline & & $\begin{array}{l}\text { Regular market experiments for product and service } \\
\text { adaptations }\end{array}$ \\
\hline & & $\begin{array}{l}\text { More frequent introduction of new product or service } \\
\text { versions }\end{array}$ \\
\hline & & Using customer feedback and comments \\
\hline & & Better targeted marketing and prospecting activities \\
\hline & & $\begin{array}{l}\text { Data collection and use of predictive algorithms for } \\
\text { modelling and interpreting data }\end{array}$ \\
\hline & & Using data to anticipate consumer behavior \\
\hline \multirow{8}{*}{$\begin{array}{l}\text { Distance and } \\
\text { location } \\
\text { (psychological and } \\
\text { physical) }\end{array}$} & \multirow{8}{*}{$\begin{array}{l}\text { - border dematerialization } \\
\text { - acceleration of internationalization operations } \\
\text { - reduction of psychological distances } \\
\text { - activities led by networks rather than countries } \\
\text { - greater transferability of a firm's specific assets } \\
\text { - less specificity related to location } \\
\text { - reduction of dependence on location-bound } \\
\text { assets } \\
\text { - management of international activities from a } \\
\text { - creation of networks of users via platforms } \\
\text { - democratization of consumption } \\
\text { - better access to new targeted markets }\end{array}$} & $\begin{array}{l}\text { Reaching a large number of markets with the same } \\
\text { production resources }\end{array}$ \\
\hline & & Externalizing location-specific assets \\
\hline & & Developing a large community of users \\
\hline & & Partnerships with local companies via platforms \\
\hline & & Licensing products and services to local firms \\
\hline & & Sharing production and distribution sites \\
\hline & & $\begin{array}{l}\text { Prioritizing decisions on proximity with customers } \\
\text { over production costs }\end{array}$ \\
\hline & & Local and niche market development \\
\hline \multirow{7}{*}{$\begin{array}{l}\text { Relational } \\
\text { competences and } \\
\text { partner networks }\end{array}$} & \multirow{7}{*}{$\begin{array}{l}\text { - increasing number of actors in markets } \\
\text { - momentaneous markets for specific and faster } \\
\text { transactions and interactions } \\
\text { - larger market scope for selecting targeted } \\
\text { markets } \\
\text { - creation of one large virtual market for } \\
\text { international trades } \\
\text { - better access to local knowledge, network } \\
\text { skills and market actors / partners } \\
\text { - exchange-oriented rather than production- } \\
\text { oriented } \\
\text { - better reliability in relationships }\end{array}$} & Developing direct interactions with customers \\
\hline & & $\begin{array}{l}\text { Data and skills sharing between partners to reach } \\
\text { targeted networks }\end{array}$ \\
\hline & & $\begin{array}{l}\text { Setting up processes and mechanisms to maintain } \\
\text { relationships }\end{array}$ \\
\hline & & Using multiple user communities in several countries \\
\hline & & $\begin{array}{l}\text { Making sustainable use of social networks and mass } \\
\text { media }\end{array}$ \\
\hline & & Collaborating with opinion leaders and change agents \\
\hline & & Building and maintaining a strong online reputation \\
\hline
\end{tabular}

Source: from the authors 